\title{
Off the Rails: Cost Performance of Australian Rail Infrastructure Projects
}

\author{
Peter E.D. Love ${ }^{\text {a }}$, Jingyang Zhou ${ }^{\mathrm{a}}$, Zahir Irani ${ }^{\mathrm{b}}$, David J. Edwards ${ }^{\mathrm{c}}$ and Michael C.P. Sing ${ }^{\mathrm{d}}$
}

\author{
${ }^{\text {a }}$ Dept. of Civil Engineering, Curtin University, GPO Box 1987, Perth, WA 6845, Australia \\ ${ }^{\mathrm{b}}$ Brunel Business School, Brunel University, Uxbridge, Middlesex, UB8 3PH, UK \\ ${ }^{\mathrm{c}}$ School of Engineering and Built Environment, Birmingham City University, Birmingham B4 7XG, UK \\ ${ }^{d}$ Dept. of Building and Real Estate, Hong Kong Polytechnic University, Hong Kong, SAR China
}

\begin{abstract}
Rail infrastructure investment is crucial for improving Australia's economic productivity and competiveness. Consequently, the Federal and State Governments have prioritized the development and expansion of urban, non-urban and freight rail networks. However, despite the importance placed on delivering cost efficient and effective rail infrastructure, cost overruns are a vexatious issue throughout Australia. This paper uses an exploratory case study approach to analyze the cost overruns of a homogenous dataset comprising of 16 rail projects delivered by a 'single' contractor, which accounted for more than AU \$ 1 1 2 billion of work for several incumbent Australian State Governments and asset owners between 2011 and 2014. In stark contrast to the planning and transport literature, the cost overrun was determined from the contract award for construction. As a result, a mean cost overrun of $23 \%$ was observed with scope changes accounting for $99 \%$ of the cost increase. Ten projects were delivered using a 'Traditional Lump Sum' procurement method; of note, two of these projects experienced cost underruns, with the remaining $50 \%$ incurring a mean cost overrun of $12.83 \%$. The empirical distribution of the sample that experienced cost overruns were computed and the 'best fit' probability density function was determined and found to be a Frechet 3P. The derivation of probabilities provides decision-makers with a reliable basis to determine an appropriate construction contingency based upon empirical data rather a deterministic percentage. The research recommends that: 1) risk and forecast cost contingencies should be accurately assessed during; and 2), greater utilization of collaborative forms of procurement (juxtaposed with the use of building information modelling (BIM) and systems information modelling (SIM)) will provide the public sector and asset owners greater confidence that delivering and maintaining rail network projects can be delivered cost effectively. The research presented provides much needed clarity to further explain the nature of cost overruns and affords guidance on how their occurrence can be mitigated using process and technological innovation.
\end{abstract}


Keywords: Australia, probability distribution fitting, rail projects, cost overrun, contract award 


\section{Introduction}

Rail infrastructure investment is crucial for improving Australia's economic productivity and competiveness. Consequently, the Federal and State Governments have prioritized the development and expansion of its urban, non-urban and freight rail networks (Infrastructure Australia, 2016). This infrastructural development may encompass the construction of new stations and tracks, extensions to existing lines, electrification of suburban networks, amplification and line upgrades and maintenance. The existing rail infrastructure must be maintained to optimum and exacting quality standards whilst, upgrades and new projects must be completed on time and to schedule to mitigate any adverse impact upon businesses and commuters. Yet, rail projects in Australia continue to experience significant cost overruns and delays, particularly urban rail projects (i.e. in excess of AU\$1 billion) such as the Gold Coast light rail, Moreton bay rail link, Sydney light rail and the Perth-Mandurah rail line.

Evidence indicates that cost overruns incurred on rail infrastructure projects is a worldwide phenomenon (e.g., Leavitt et al., 1993; Flyvbjerg et al., 2007; Canteralli et al., 2012a,b,c). For example, in the United Kingdom (UK) the Edinburgh Tram System experienced a cost overrun in excess of $100 \%$. Whilst in the United States (US), several high profile rail projects have experienced significant overruns (Grabauskas, 2015), namely: the US $\$ 1.8$ billion central link lightrail project in Seattle was 38\% over budget; Phoenix's US\$1.07 billion East Valley light-rail project was 31\% budget; San Francisco's US $\$ 1.2$ billion airport heavy-rail project, 30\% over budget; and Los Angeles' US $\$ 3$ billion heavy-rail red line project, $47 \%$ over budget. These cases reiterate a perpetual story for taxpayers; shortfalls result in increased debt and increased taxes, which can often stem generations to repay the borrowed monies of government. This situation is exemplified in the Honolulu rail transit project that commenced in 2008 - the project was expected to cost US $\$ 4$ billion to construct (Mangieri, 2016) and is expected to exceed US $\$ 10$ billion upon completion (Daysog, 2016).

Major causes of cost increases on the Honolulu rail transit project are the limited supply of labor and the increasing cost of materials (Shimogawa, 2016). When preparing the project budget, forecasting the supply and demand of labor and materials is an arduous, and in some instances, impossible task to determine, especially when estimators have to forecast construction costs 
months or even years in advance; in this instance 'uncertainty' prevails and 'guesstimating' occurs (Sing et al., 2012; Sing et al., 2016). For example, the Sydney light rail project and Edinburgh Tram System, under estimation of the cost of moving utilities such as power cables significantly contributed to increased construction costs (Saulwick, 2014). Importantly, 'as-built' documentation for power cables seldom exist or are often inaccurate (Love et al., 2016a). Individual cities are characteristically unique (i.e. in terms of their layout and structures), hence, it is unrealistic to assume that an accurate forecast of the underground utilities that may be required to be re-located could be undertaken. A 'provisional sum' (i.e. an allowance for undefined work) is typically provided when this situation arises (Smith et al., 2016). For urban rail mega-projects, estimators must often determine an initial budget for construction costs, months, years or even decades in advance. Thus, a design contingency (i.e. allocated for changes during design for factors such as incomplete scope definition and estimating inaccuracy) is required and subsequently reduced as more information becomes available. Prior to the commencement of construction, a contingency (i.e. where any unresolved design issues at the time of contract award are incorporated into the estimate/contract price) is also needed, though this often calculated deterministically rather using a probabilistic approach (Love et al., 2015a; Love et al., 2016b).

Research undertaken by Flyvbjerg (2007) and Canteralli et al. (2012c), provided an initial platform for understanding cost overruns in rail projects, particularly those classified as being 'mega' in size and complexity. Issues surrounding strategic misrepresentation, optimum bias and political machinations abounding have been over-emphasized in the planning and transport literature (e.g., Siemiatycki, 2009), with much of the research propagated being incorporeal (e.g., Love et al., 2012a; Osland and Strand 2015). Despite insufficient evidence presented by Flyvbjerg (2007), the research (ibid) has attracted media attention and opposition political parties, and has undoubtedly served as reference point from which to comprehend why mega rail projects experience cost overruns. Rather than focusing on 'mega' projects, this paper examines overruns cost for rail projects commissioned by several incumbent Australian State Governments and asset owners to improve the productivity and performance of their region and businesses operating within it. A case study approach is used to analyze overrun costs of a homogenous sample of rail projects delivered by a 'single' contractor between 2011 and 2014. The research presented 
provides a much needed clarity to further explain the nature of cost overruns and affords guidance on how their occurrence can be mitigated using process and technological innovation.

\section{Cost Overruns and Rail Projects}

While the extant literature is replete with studies that have examined cost overruns in transportation infrastructure projects (e.g. Bordat et al. 2004; Odeck, 2004; Vidalis and Najafi, 2004; Liu et al., 2010; Canteralli et al., 2012a,b,c; Love et al., 2015a; Odeck et al., 2015; Verweji et al., 2016a), the number of studies that have focused on rail projects is limited (e.g., Pickrell, 1990; Fourace et al., 1990; Leavitt et al., 1993; Dantata et al., 2006; Flyvbjerg et al., 2007). Moreover, the sample size of projects examined has been small, ranging from as low as 10 (Pickrell) to a maximum of 169 (Canteralli et al., 2012c). According to Flyvbjerg (2007) rail tends to experience the largest cost overrun of all the types of transportation projects with a mean of $44.7 \%$.

The reported mean cost overrun however, differs significantly between studies in various countries; for example, 50\% in the US (Pickrell, 1990), 10.6\% in the Netherlands (Canteralli et al., 2012c) and 17\% in Sweden (Lundberg et al., 2011). A primary reason for this observed disparity is the 'point of reference' from where the cost overrun is measured (Love et al., 2015a; Love et al., 2016a). Within the planning and transport fraternity, cost overruns are the difference between initial forecasted budget and actual construction costs (Canteralli et al., 2012a). Between the initial forecasted budget of construction costs and the commencement of construction, several estimates will be prepared and refined before being lodged for approval. Odeck (2004) however, suggested that the reference point for a cost overrun should be at the detailed planning stage where design, specification and final cost are determined. Similarly, Love et al. (2015a) advocated that cost overruns should be determined at the point of contract signature to undertake construction. At this juncture, a degree of cost certainty can be provided to an asset owner subject to the procurement method adopted and completeness of tender documentation provided to the party/ parties (i.e. contractor/consortium/joint venture) contracted to perform the required works. 
A significant omission by Flyvbjerg (2007) and Canteralli et al. (2012a,b,c) is that they have not acknowledged the influence that a procurement method and contract can have on a project's costs. For example, if a rail project is delivered as an alliance contract, then the consortium can be 'locked-in' by the contract to provide a Guaranteed Maximum Price (GMP) based on an initial budget estimate. Using procurement methods of this ilk, transfers 'design' and 'construction' risks to a single entity. In addition, if a Public-Private Partnership or variant thereof such as Design Build Operate and Maintain is used, then at what point is a cost overrun determined? At the conclusion of construction or when the asset is handed over back to the government when the operations and maintenance (O\&M) phase has been completed (Liu et al., 2016). Essentially, the 'bundling' up of capital and operating costs have been largely ignored in the planning and transport literature.

A comprehensive review of factors influencing the variability between an initial forecasted budget and final tender sum has been provided in Adafin et al. (2016a,b) and includes: changes in owner/stakeholder requirements, planning requirements or restrictions, market conditions (e.g., fluctuations in labor prices), poorly prepared documentation, availability of design information and government legislation/policy. Issues, however, that have been eschewed by Adafin et al. (2016a) are optimism bias and strategic misrepresentation that may be used to influence the budget estimate and its subsequent management during the design development process. As noted above, to determine how the aforementioned issues influence the costs up to the point where a contract is signed prior to the commencement of construction is highly subjective.

Irrespective of the point that is used to determine the percentage cost overrun experienced, there is broad consensus that rail projects globally are typically confronted by unnecessary expenditure increases. In Australia, State Governments and their transport infrastructure delivery agencies have been criticized in the media (e.g. Moore 2016), by lobby groups (e.g., Eco-Transit, 2015) and State Auditors (e.g., NSW Audit Office 2010; VAGO, 2010) over the escalating cost of rail projects. According to Martin (2011) State Governments need to acquire improved knowledge about project costs for their rail projects so as to develop more robust and reliable business cases. An analysis of 26 major public rail projects delivered in Australia between 2000 and 2009 (Martin, 2011) revealed significant differences in construct costs per km: for example, the 12 kilometer $(\mathrm{km})$ 
Epping Chatswood Railway line in Sydney (heavy suburban line) was the most expensive at AU\$193.36 million per km, whereas the 72km Perth-Mandurah Line (heavy suburban line) was a fraction of the cost, at a mere AU\$17.36 million per $\mathrm{km}$. The cost difference between these two projects, has engendered a perception that rail costs are higher than they should be in cities such as Sydney and Melbourne (Gatenby, 2009; Martin, 2011).

\section{Research Approach}

The research undertaken by Flyvbjerg (2007) and Canteralli et al. (2012a,b,c) relied upon 'blackbox' international database that afforded limited information about how their data was collated and why there was a reliance upon secondary sources. More specifically, the reliability of data presented in Canteralli et al. (2012c) is questionable because they state "if the actual costs are unknown at the time of project completion, the most reliable later figure for actual costs is used (i.e. from a year later than the opening) if available. If unavailable, an earlier figure for actual costs could be used (i.e. from a year before the opening year), but only if $90 \%$ of the budget was spent at this time i.e. the project was 90\% complete in financial" (p.326). The authors (Canteralli et al. 2012c) fail to adequately elucidate upon why and how was $90 \%$ determined in this instance and what percentage of projects were deemed $90 \%$ complete . In addition, they make a comparison with Flyvbjerg et al.'s (2002) original dataset of 258 projects, which was collected from projects completed in different time points and from an array of countries; construction techniques, technologies, legal jurisdictions, political and economic environments, client types and procurement arrangements all differed, yet these limitations were overlooked (Love et al., 2015a).

This paper seeks to ameliorate understanding about cost overruns in rail projects and used an exploratory case study approach to obtain primary cost data from a homogenous data source from a contractor with extensive experience of undertaking these projects (Shields and Rangarjan, 2013). . The contractor had previously collaborated with the research team with on other studies and was willing to disclose contract information on rail projects that had been constructed between 2011 and 2014. Projects that had commenced in 2015 and progressing in 2016 were excluded from the research. Due to the commercial sensitivity of the data provided, only a brief description of each project is provided. Table 1 provides information about the types of project, the procurement methods used, the classification, location, original contract value, the cost change and the amount 
of scope changes that were incurred. While asset owners sanctioning the identified projects were different, the contractor's processes (e.g., quality assurance systems, safety management and contract administrative procedures), technologies, and construction methods were standardized. In addition, the procurement methods used are also very similar, though this is often reflective of the business case that is established, the risk and complexity of the projects and prevailing economic conditions (Love et al., 2012b).

\section{Analysis}

Descriptive statistics such as the mean (M), standard deviation (SD), and inter-quartile were calculated for the 16 rail projects constructed by the contracting organization. A Probability Density Function (PDF) was computed for a continuous distribution so that the likelihood for rail projects experiencing a cost overrun to be undertaken. The probability that is obtained can establish a construction contingency that is useful for public and private sector asset owners and contractors. Scope changes consume additional resources (e.g., labor, materials, and equipment) and can adversely impact schedule, a contractor must be proactive and 'anticipate what might go wrong' by employing mechanisms to ensure a project meets its expected deliverables.

The PDF for a continuous distribution can be expressed in terms of an integral between two points:

$P=\int_{a}^{b} f(x) d x \quad a \leq x \leq b$

A cumulative distribution functions (CDF) was also produced. For theoretical continuous distributions the CDF is expressed as a curve and denoted by:

$$
F(x)=\int_{-\infty}^{x} f(t) d t
$$

The empirical CDF, which is displayed as a stepped discontinuous line and dependent on the number of bins, is represented by: 


$$
F_{n}(x)=\frac{1}{n} \cdot[\text { Number of observations } \leq x]
$$

The PDF, Cumulative Distribution Functions (CDF) and distribution parameters $(\alpha, \beta, \gamma, \mu, k, m, \sigma, \xi)$ for continuous distributions such as Beta, Burr, Cauchy, Error, Gumbel Max/Min, Johnson SB, Normal, and Wakeby were examined using the estimation method Maximum Likelihood Estimates. The 'best fit' distribution was then determined using the following 'Goodness of Fit' tests, which measure the compatibility of a random sample with a theoretical probability distribution:

- Anderson-Darling statistic $\left(A^{2}\right)$ : A general test to compare the fit of an observed CDF to an expected CDF. The test provides more weight to a distributions tails than the KolmogorovSmirnov test. The Anderson-Darling statistic is defined as:

$$
A^{2}=-n-\frac{1}{n} \sum_{i=1}^{n}(2 i-1) \cdot\left[\operatorname{In} F\left(x_{i}\right)+\operatorname{In}\left(1-F\left(x_{n-i+1}\right)\right)\right]
$$

- Chi-squared statistic $\left(\chi^{2}\right)$ : Determines if a sample comes from a population with a specific distribution. The Chi-squared statistic is defined as:

$$
\chi^{2}=\sum_{i=1}^{k} \frac{\left(O_{i}-E_{i}\right)^{2}}{E_{i}}
$$

- Kolmogorov-Smirnov statistic $(D)$ : Based on the largest vertical difference between the theoretical and empirical CDF:

$$
D=\max _{1 \leq i \leq n}\left(F\left(x_{i}\right)-\frac{i-1}{n}, \frac{i}{n}-F\left(x_{i}\right)\right)
$$


where $O_{i}$ is the observed frequency for bin $i$, and $E_{i}$ is the expected frequency of bin $i$ calculated by:

$$
E_{i}=F\left(x_{2}\right)-F\left(x_{1}\right)
$$

Here $F$ is the CDF of the probability distribution being tested, and $x_{1}, x_{2}$ the limits for the bin $i$.

The above 'Goodness of Fit' tests were used to test the null $\left(H_{o}\right)$ and alternative hypotheses $\left(H_{l}\right)$ of the datasets: $H_{0}$ - follow the specified distribution; and $H_{1}$ - do not follow the specified distribution. The hypothesis regarding the distributional form is rejected at the chosen significance level $(\alpha)$ if the statistic $D, A^{2}, \chi^{2}$ is greater than the critical value. For the purposes of this research, a 0.05 significance level was used to evaluate the null hypothesis.

The $p$-value, in contrast to fixed $\alpha$ values is calculated based on the test statistic and denotes the threshold value of significance level in the sense that $H_{o}$ will be accepted for all values of $\alpha$ less than the $p$-value. Once the 'best fit' distribution was identified, the probabilities for a cost change were calculated using the CDF. Then, to simulate the samples randomness and derive the probabilities of a cost overrun (e.g., scope changes in this case) arising during construction, a Mersenne Twister, which is pseudorandom number generating algorithm, was used to generate a sequence of numbers that approximated the sample to 5000 (Matsumoto and Nishimura, 1998). 


\section{Results}

The total value of rail projects that had been originally awarded to the contractor during 2011 and 2014 was AU\$539,569,997, with an $\mathrm{M}=\mathrm{AU} \$ 33,723,124$ and SD = AU\$78,398,023 (Table 1). The total value of work that was undertaken was AU\$665,479,369, an increase of 19\%. This additional increase was predominately due to client initiated scope changes. Two rail projects incurred cost increases other than the scope changes that were approved by their clients, namely an 'Urban Track Upgrade' and the 'Installation and Maintenance of Concrete Sleepers', which experienced non-conformances accounting for AU\$397,978 and AU\$115,560, respectively. Noteworthy, two projects experienced a cost underrun due to changes in scope. Table 1 reveals that a variety of rail projects were undertaken such as 'New Build' (50\%) and a combination of 'New Build and Upgrades' (25\%) with most being constructed in Western Australia (WA) (63\%).

A total of $10(63 \%)$ rails projects were procured using a 'Traditional Lump Sum' method, with 3 (19\%) by 'Traditional Cost-plus', 2 (13\%) by 'Design and Construct' and 1 (6\%) using an Alliance contract. The three projects that used a 'Traditional Cost-plus' were for a private sector client. The 'Alliance' project, which was the largest rail project undertaken by the contractor, was undertaken in Victoria and formed part of one of Australia's largest public infrastructure projects. The Victorian State Government used an 'Alliance' contract because the capital costs for this high risk complex project exceed AU\$50 million. The works included new tracks to be laid, the construction of new rail overpasses, modifications to existing bridges, extensive track reconfiguration and the upgrading of signaling systems.

The mean cost overrun from the contract award for the 16 sampled projects was $23 \%$ (Table 2). Interestingly, two were delivered using a 'Traditional Lump' method (13\%) experienced cost underruns, with the remaining $50 \%$ incurring a mean cost overrun of $12.83 \%$. The maximum cost overrun was $96.73 \%$ and the minimum was $-4.19 \%$. If the initial budget estimate (also referred as the 'Time of formal decision to build (ToD))' (Canteralli et al., 2012c) had been used as the point of reference to determine the cost overrun, then there is no doubt that the figures presented would be significantly inflated. For the 'Iron Ore' project, which incurred a cost overrun of 96.73\%, the original scope of works was AU\$1,200,000 and increased to AU\$36,691,000. The contractor, was initially required to undertake site preparation works, but as the mine owner was under pressure to 
commence operations and ship its iron ore to market, new works were added to the existing costplus contract (i.e. the contractor was paid for their expenses, which were to a set limit plus an additional payment for profit), which was in place instead of approaching creating a new one. If a new contract had been created then a cost overrun would not have been registered.

\section{Distribution Fitting: Probability of Cost Change}

The 'best fit' probability distribution was determined using the following 'Goodness of Fit' tests: Anderson-Darling, Chi-squared statistic and Kolmogorov-Smirnov. The results of the 'Goodness of Fit' tests revealed that Three Parameter (3P) Frechet distribution provided the best fit for the dataset (Table 3).

< Insert Table 3. Goodness of Fit Tests for rail projects >

A Frechet is a form of generalized extreme value distribution (GEV) that is used as an approximation to model the maxima of long (finite) sequences of random variables (Coles, 2001). The PDF is expressed as:

$$
f(x)=\frac{\alpha}{\beta}\left(\frac{\beta}{x-\gamma}\right)^{\alpha+1} \exp \left(-\left(\frac{\beta}{x-\gamma}\right)^{\alpha}\right)
$$

The CDF is expressed as:

$$
f(x)=\exp \left(\left(-\frac{\beta}{x-\gamma}\right)^{\alpha}\right)
$$

$\alpha$ is a continuous shape parameter with $\alpha>0 . \beta>0$ and $\gamma$ is a continuous location parameter where $\gamma \equiv 0$ yields the two parameter-Frechet distribution. The domain for the 3P Frechet distribution is $\gamma<x<+\infty$. 
The parameters for the Frechet (3P) were found to be $\alpha=2.496, \beta=31.459$ and $\gamma=-22.568$. Figures 2 and 3 present the PDF and CDF based upon the calculated distribution parameters. The calculated probabilities of a cost overrun being experienced are presented in Table 4. The probability of experiencing a cost change of $>10 \%$ is $32 \%$. Delimiters have also been used to provide probabilities of cost changes within ranges. The probability of a project experiencing between a $15 \%$ and $25 \%$ cost change, for example, is $17 \%$ (Figure 4 ). For a mean cost overrun of $23 \%$ to be experienced the likelihood of occurrence is $60 \%(\mathrm{P}(\mathrm{x}<\mathrm{x} 1)=.67)$ from contract award. Explicitly, the construction cost contingency for 14 of the sampled projects was unable to accommodate the scope changes that were needed for them to serve their intended purpose. At contract award, Buertey et al. (2013) have suggested using a contingency value of $3 \%$ to $5 \%$ of a project's contract value is required to accommodate unresolved design issues.

\section{Discussion}

Delivering rail projects within their forecasted construction cost is a priority for public and private sector organizations. The analysis demonstrates the likelihood of rail projects exceeding a $20 \%$ overrun is high considering current practices. In an attempt to ensure cost certainty in rail projects, procurement methods such as 'Traditional Lump Sum', 'Design and Construct' and 'Alliances' are often employed. In the case of a 'Traditional Lump Sum' method the public sector accepts that design work will generally be separate from construction. Consultants are appointed for design and cost control, and the contractor is responsible for carrying out the works for a fixed sum. This responsibility extends to all workmanship and materials, and includes all work by subcontractors and suppliers. The contractor is usually appointed by competitive tendering on complete information but may if necessary be appointed earlier by negotiation on the basis of partial or notional information. The contractor undertakes to carry out a defined amount of work in return for an agreed sum.

According to Love et al. (2012b) the concept of cost certainty is a fallacy when using traditional methods that are based upon full drawings and bills of quantities (BoQ). In principle this approach should provide a firm, fixed price for construction, but in practice very few projects are actually completed within their tendered price (Rowlinson, 1999); this was clearly evident in the rail projects examined. Complete drawings and BoQs are generally unavailable to contractors when a 
project goes to tender and documentation that is provided often contains errors and omissions, which may initiate scope changes and rework during construction (Love et al., 2012a).

With 'Design and Construct' methods a contractor accepts responsibility for some or all of the design. Design and construct methods offer certainty on the contract sum with the provision of a GMP and bring cost benefits. The close integration of design and construction methods and the relative freedom of the contractor to use their purchasing power and market knowledge most effectively affords public and private sector clients with a competitive price. However, changes in scope can be costly. Considering the inherent degree of cost certainty that this form of procurement method provides it was surprising to find that costs had increased. However, both projects in question were constructed in an urban environment; a close examination of the scope changes revealed that additional work was required to relocate underground utilities. Similarly, the scope changes approved by the public authority generally related to unexpected signaling issues and integrating newly installed communication systems with an existing mainline station power distribution network.

It has been widely acknowledged that collaborative procurement methods such as 'Alliances' and 'Design and Construct' and 'PPPs' provide improved cost performance and value-for-money for the public sector (e.g. Muriro and Wood, 2010). In fact, PPPs consistently demonstrate superior cost efficiency over traditional methods ranging from $30.8 \%$ (from project inception) to $11.4 \%$ (from contractual commitment to final outcome) (Infrastructure Partnerships Australia, 2008). Despite these reported cost benefits, PPPs have also received widespread criticism, particularly with dealing with risk transfers over an assets life (e.g. Hodge, 2004). The Latham (1994) and Egan Reports published in the UK (1998) served as a catalyst for reforming the construction industry so that project performance would improve. Yet, 20 years later, the level of cost overruns occurring has not diminished; a conclusion also propagated by Flyvbjerg et al.(2003). Cost overruns, will remain a pervasive problem unless fundamental changes are made to the governance and procurement of projects (e.g., collaborative relationship contracting, and bundling), and technological innovations are embraced. Radical reform is needed to improve the cost performance and management of information throughout the assets life (Love et al., 2015a). 


\section{Improving Cost Estimation}

Following strategic justification, which examines what is required to meet client demands and needs, an initial budget estimate is prepared. Typically, the initial estimate increases as the project progresses through the design development process. Constantly revising and amending the initial budget is disruptive and may have concomitant shortfalls in funding occurring (Department of Transport and Main Roads, 2015). The performance of an initial budget estimate can only be assessed when a project is completed, hence sufficient design contingency must be included to accommodate changes in project scope. During this stage, those responsible for preparing the initial budget estimate may succumb to optimism bias.

To ensure the reliability of the initial budget estimate and contingency, external professionals' advice and evaluation, particularly cost consultants (e.g., quantity surveyors), should be sought. In-line with contemporary procurement thinking (e.g., Loosemore, 2016), a paradigm shift-away from traditional to relational methods is needed which involves contractors in vetting initial budgets. Indeed, this controversial idea challenges questions associated with probity. Nevertheless, the aim here would be to remove 'uncertainties' and identify potential risks that may materialize; the inclusion of a contractor's early input in the design process would improve a project's constructability and provide a platform engendering collaboration between parties. When contractors assess the initial budget they could also identify innovative alternative methods of construction; any advice provided would be fee-based and issues associated with intellectual property would require resolution, if they were not awarded a contract to deliver the works. As a project moves through its various development stages key decision-makers and policy advisors would sign-off and approve the evolving estimate.

At the initial budget stage, a contingency of $30 \%$ to $50 \%$ should be allowed for incomplete scope and $5 \%$ to $10 \%$ for estimating inaccuracies (Clark and Lorenzoni, 1985). Therefore, as a rule of thumb, a $35 \%$ to $60 \%$ design contingency should be added to the initial budget estimate figure. For example, the Department of Transport and Main Roads (2015), expect that initial budget estimates have a $90 \%$ confidence factor (P90) of not being exceeded at completion. Producing an estimate with such a high confidence factor is dependent upon having access to good quality information (e.g., costs from previous projects, specific requirements of stakeholders, procurement 
options, and market conditions). A series of cost scenarios that can materialize in projects are presented in Figures 5 to 7. The ideal scenario is one where the budget estimate that is established excluding the contingency equals the final cost. This is an unlikely scenario considering the existing practices and processes that are used to design and construction rail projects and, the limited understanding of the systemicity and interdependency of risk (Love et al., 2016a).

$<$ Figure 5. The ideal cost scenario >

$<$ Insert Figure 6. An acceptable cost scenario >

< Insert Figure 7. Unacceptable cost scenario >

In the projects sampled, an unusually high proportion of cost overruns were due to scope changes. The nature of these changes could not be quantified but considering previous empirical research undertaken, they were likely to be attributable to client initiated design changes, errors or omissions contained within the design documentation (Love et al., 2004). For the rail projects presented in this research, the probability of scope change is established based on existing practices to document and management information, which was undertaken using Computer-Aided-Design (CAD) by independent specific disciplines.

\section{Improving Information Quality}

Figure 7 illustrates an unacceptable cost scenario which may well have arisen within projects procured via 'Cost-plus' methods. In such situations there is an overwhelming precedence to ensure that the rail asset operates expediently which can inadvertently result in a poorly defined scope. To reduce scope changes, and improve the quality of decision support information (required throughout a rail assets life, particularly during design and construction), technological and process innovations such as Building Information Modelling (BIM) (Figure 8) and Systems Information Modelling (SIM) (Figure 9) should be implemented simultaneously (Love et al., 2016c).

The US National Building Information Model Standard Project Committee (2015) defined BIM as "a digital representation of physical and functional characteristics of a facility. A BIM is a shared knowledge resource for information about a facility forming a reliable basis for decisions during 
its life-cycle, which is defined as existing from earliest conception to demolition". A SIM, however, is a derivative of BIM, but represents a process of modeling complex connected systems, such as electrical control, power and communications (herein after electrical systems), which do not possess geometry (Love et al., 2016b). Essentially, a SIM takes a discipline specific perspective but can be integrated within a BIM when a single point of truth is formed.

When a SIM is applied to engineer and document a system, all the physical equipment and associated connections, similarly to constructing a BIM, are modeled in a relational database with each component modeled only once resulting in a 1:1 relationship between the SIM and the real world. However, when using traditional CAD (as preferred method to document the design of electrical systems within the rail sector), each object in the real world may appear on multiple drawings and each drawing may contain a number of objects. Thus, an n:n relationship (i.e., $n$ number of objects appear on n number of drawings) is formed between the real-world objects and the drawings. Hence, the propensity for errors and omissions to materialize significantly increases as changes to individual CAD drawings that contain the same object need to be undertaken and up-dated manually.

< Insert Figure 8. Extracts from a Building Information Model from a rail project>

< Insert Figure 9. Creation of a retrospective Systems Information Model from a rail project >

When BIM is used to establish an initial budget estimate, its visualization capacity can explore design solutions and conduct preliminary construction programming, life-cycle costing, functional analysis and cost benchmarking. From the on-set, stakeholders can visualize the rail asset and make critiques and modifications while instantaneously being able to determine the impact on the project's cost. As the design and engineering mature, costs can be monitored and alternative options analyzed. With the early involvement of a contractor, the potential of optimism bias significantly diminishes, as 'checks and balances', as well as costs that reflect actual market prices can be considered and brought to the fore. 
Early contractor involvement may not always be feasible and practical, and will invariably depend upon the project's value (Rahman and Alhassan, 2012). However, this does not discount the influence that the independent design team can exert in using BIM to ensure the constructability and cost effectiveness of various options that may be put forward for consideration. As noted in Figure 8, during the rail of a tunnel its alignment can be modelled juxtaposed with Geographical Information Systems, track schedule progress can be tracked and visualized (4D), and cost and schedule progress of stations can be simultaneously visualized (5D).

Working within a BIM environment will significantly reduce scope changes and provide greater cost certainty, particularly during construction (Hartman et al., 2012). It is therefore anticipated that when BIM is applied to rail projects, the probability of cost overruns being incurred will dramatically change. To achieve the real benefits of a BIM solution requires collaboration between all parties who are selected to deliver a rail asset, particularly when there is a requirement for ensure a BIM is required to minimize costs during O\&M. London’s £14.8 billion Crossrail network project exploits BIM to help planners integrate the new train lines into existing infrastructure (Peplow, 2016). According to Peplow (2016), the use of BIM has saved time and money by reducing construction errors, which often manifest as additional scope changes or rework costs. The use of clash detection, laser scanning, compliance checking, sensors to check and monitor the integrity of the rail network, have all contributed to ensure mitigating scope changes and rework in Crossrail, and have assured assets integrity for O\&M.

Rail projects are dependent on electrical systems to function. Like BIM, a SIM can establish the initial budget estimate for such systems and provide approximate quantities as cable lengths, connectors and devices when the route for the project has been established. Empirical research has demonstrated that the use of a SIM during design can provide as much as a $90 \%$ reduction in the amount time and cost to prepare documentation (Love et al., 2013). In addition, a SIM significantly reduces the proclivity for errors and omissions to be made as well as information redundancy in documentation thereby minimizing scope changes during construction.

Provide information in a format that does not possess 'noise' is an essential ingredient in developing an initial budget estimate for electrical systems. Rail projects often require up-grades 
to tracks and maintenance and estimating the cost of such projects requires an understanding of not only the new work to be undertaken but also the existing network. Using 3D laser scanning hiresolution imagery from linear and real world positions, the existing network can be integrated with the new design and costed appropriately (Figure 8).

\section{Limitations}

Akin to the research conducted by Flyvbjerg (2007) and Canteralli et al. (2012c), this research presented has limitations. The most notable is the sample size, which was limited to 16, although a Mersenne Twister, was used to generate a sequence of pseudorandom numbers that approximated the sample to 5000. The data, however, is homogenous, reliable and is reflective of 'actual' costs that were incurred. While the projects were diverse in their geographical location, they are not representative of Australia; absent territories included the Australian Capital Territory (ACT), Northern Territory (NT), Queensland (QLD) and Tasmania. This is important considering that New South Wales and Victoria have been identified as experiencing higher construction costs for rail than other States and Territories.

Unfortunately, the findings could not be compared with Flyvbjerg (2007) and Canteralli et al. (2012c) as procurement methods, construction costs, scope changes incurred, and economic conditions were not presented. In addition, Flyvbjerg (2007) focused upon 'mega' projects, which are unique when likened to the general works programs undertaken by State Governments and asset owners and therefore, the results presented in this paper are not able to be compared. The economic climate within which projects were undertaken between 2011 and 2014 was significantly different between Australia States and the ACT and when Flyvbjerg (2007) and Canteralli et al. (2012c) conducted their studies. For example, WA (also NT and QLD, though projects were

constructed by the contractor from 2011 to 2014) was experiencing an economic boom and significant increases in population growth due a to demand for energy mineral resources, while other States and the ACT were experiencing significantly reduced levels economic activity.

\section{Conclusions}

The cost performance of rail infrastructure projects has received considerable attention as they are seldom delivered within budget, particularly those classified as being 'mega' projects. 
Consequently, research has focused upon projects of this magnitude and provide explanations as to 'why' and 'how' cost increases arise. The justifications put forward while plausible are divorced from actual data presented, even the solutions for improving the accuracy of budget estimates do not reflect the complexity, systemicity and interdependency of risk that can arise during the delivery of rail projects.

Recognizing these shortcomings, this paper examines the cost performance of a homogenous sample of 16 rail projects that were constructed by a single contractor. Cost performance for the rail projects was calculated from the contract award until final completion; this is in stark contrast to the extant planning and transport literature that has predominantly focused on using the initial budget estimate or the decision to build is made as reference point for cost performance determination. Consequently, the determination of cost performance from contract award provides a realistic measure, as scope changes as information becomes available during the design process. The analysis revealed that a mean cost overrun of $23 \%$ of the contract value, with $99 \%$ of the total cost increase incurred being due to scope changes. Considering prevailing practice, the probability of cost overruns arising were determined so that adequate contingency could be established in the future. It appears, however, that the historic magnitude of cost increases being experienced in rail projects have not decreased in the fifty years or more.

In addressing this problem, a paradigm shift in the way that the initial budget estimate and its development must be undertaken by the public sector and asset owners. Such change should include:

- the determination of contingencies based upon probabilistic methods such as distribution fitting identified and demonstrated in this research, particularly for construction;

- the greater use of collaborative procurement methods such as Alliances, which includes financial incentives to ensure guaranteed maximum prices;

- $\quad$ third party audit of the initial budget by external consultants to minimize the potential for optimism bias; 
- involvement of contractors, particularly those specializing in electrical systems early in the design process to provide constructability advice with particular emphasis being placed on the evaluation of initial budget estimate; and

- $\quad$ the use of BIM and SIM, which can be used to mitigate scope changes.

The cost overrun phenomena is a complex and challenging problem to address. This paper does not attempt to provide complete answers but rather serves to suggest a novel way forward in dealing with this issue. There is a need, however, to better assess risk and forecast cost contingencies, but the use of collaborative forms of procurement juxtaposed with the use of BIM and SIM will provide public sector and asset owners (charged with delivering and maintaining rail networks) greater confidence that projects can be delivered cost effectively.

Acknowledgment: The authors would like to acknowledge the financial support provided by the Australian Research Council (DP160102882).

\section{References}

Adafin, J., Rotimi, J. O. B., and Wilkinson, S. (2016a). Determining significant risks in the variability between design stage elemental cost plan and the final tender sum. ASCE Journal of Management in Engineering, 10.1061/(ASCE)ME.1943-5479.0000448

Adafin, J., Wilkinson, S., Rotimi, J. O. B., and Odeyinka, H. (2016b). Evaluating the budgetary reliability of design stage elemental cost plan in building procurement. Cape Town: Proceedings of the $9^{\text {th }}$ CIDB Postgraduate Conference, Dept. of Construction Economics and Management, University of Cape Town, South Africa, pp.60-70

Baccarini, D., and Love, P.E.D. (2014). Statistical characteristics of contingency in water infrastructure projects. ASCE Journal of Construction Engineering and Management, 140(3), 04013063.

Bordat, C.B., McCulloch, K.C., Sinha, K.C., and Labi, S. (2004) An Analysis of Cost Overruns and Time Delays of INDOT Projects. Publication FHWA/IN/TRP-2007.04. Joint 
Transportation Research Program, Indiana Department of Transportation and Purdue University, West Lafayette, Indiana, 2004. doi 10.573/1288284313134.

Buertey, J. I. T., Inga, E., and Kumi, T. A. (2013). The financial impact of risk factors affecting project cost contingency: evidential reasoning method. Journal of Engineering, Project, and Production Management, 3(2), p.65.

Cantarelli, C.C. van Wee, B., Molin, E.J.E., and Flyvbjerg, B. (2012a) Characteristics of cost overruns for Dutch transport infrastructure projects and the importance of the decision to build and project phases. Transport Policy, 22, pp.49-56.

Cantarelli, C.C. van Wee, B., Molin, E.J.E., and Flyvbjerg, B. (2012b) Different cost performance: different determinants? The case of cost overruns in Dutch transport projects. Transport Policy, 22, pp.88-95.

Cantarelli, C.C., Flyvbjerg, B. and Buhl, S.L. (2012c) Geographical variation in project cost performance: the Netherlands versus worldwide. Journal of Transport Geography, 24, pp.324-331.

Dantata, N. Touran, A., Schneck, D.C. (2006). Trends in US rail transit project cost overrun. Transportation Research Board 85th Annual Meeting, $3^{\text {rd }}$ March, Transportation Research Board, Washington D.C, 06-0897, (Available at: http://www.honolulutraffic.com/Dantata06-0897.pdf, Accessed $5^{\text {th }}$ August 2016)

Department of Transport and Main Roads. (2015). Project Cost Estimating Manual. Sixth Edition, September 2015, Department of Transport and Main Roads, State of Queensland, Brisbane, Australia (Available at: http://www.tmr.qld.gov.au/business-industry/Technical-standards-publications/Project-cost-estimatingmanual.aspx, Accessed, $1^{\text {st }}$ August 2016).

Eco-Transit (2015). NSW Government steals Western Sydney's future with over-priced light rail. $8^{\text {th }}$ December 2015. (Available at: http://ecotransit.org.au/wp/2015/12/08/nsw-government-steals-western-sydneys-futureover-priced-light-rail/, Accessed $9^{\text {th }}$ August 2016)

Egan, J. (1998) Rethinking Construction: Report of the Construction Task Force, London: HMSO Flyvbjerg, B., Holm, M.K.S. and Buhl, S.L. (2002) Understanding costs in public works projects: Error or lie? Journal of the American Planning Association, 68, pp.279-295.

Flyvbjerg, B. Bruzelius, N., and Rothengatter, W. (2003) Megaprojects and Risk: An Anatomy of Ambition, Cambridge University Press, Cambridge, UK

Flyvbjerg, B. (2007). Cost overruns and demand shortfalls in urban rail and other infrastructure. Transportation Planning and Technology, 30(1), pp. 9-30. 
Fourace, P.R., Allport, R.J., and Thomson, J.M. (1990). The Performance and Impact of Rail Mass Transit in Developing Countries, Research Report No.28, (Available at: http://www.transportlinks.org/transport_links/filearea/documentstore/249_RR278\%5B1\%5D.pdf, Accessed $9^{\text {th }}$ August 2016)

Gatenby, G. (2009). Why rail projects in NSW cost three times as much as they should. Crikey, $26^{\text {th }}$ March, (Available at: www.crikey.com.au/2009/03/26/why-rail-projects-in-nsw-cost-three-times-as-much-as-they-should, Accessed $9^{\text {th }}$ August 2016)

Grabauskas, D. (2015). How much will it cost in the end? Hawaii Business, Available at: http://www.hawaiibusiness.com/how-much-will-it-cost-us-in-the-end/, Accessed $2^{\text {nd }}$ August 2016)

Hartman, T., van Meerveld, H., Vossebeld, and Adriaanse, A (2012). Aligning building information model tools and construction management methods. Automation in Construction, 22, pp.605-613.

Hodge, G.A. (2004). Risks in Public Private Partnerships: Shifting, sharing or shirking? The Asia Pacific Journal of Public Administration, 26,(2), pp.155-179.

Infrastructure Partnerships Australia (2008). Infrastructure Partnerships Australia, Australian Constructors Association and Australian Industry Group, Submission to Infrastructure Australia Discussion Paper 2, Public Private Partnerships, October (Available at https://www.google.com.au/search?q=cost+performance+and+procurement+methods\&ie=utf- $8 \&$ oe=utf- $8 \& c$ client=firefox-b ab\&gfe_rd=cr\&ei=m5yqV77AEKbr8AeI2o6wCg\#q=minimum+budget+to+use+PPP+in+Australia, Accessed $9^{\text {th }}$ August 2016)

Infrastructure Australia (2016). Available at: Accessed 1 ${ }^{\text {st }}$ August 2016

Leavitt, D., Ennis, S., and McGovern, P. (1993). The Cost Escalation of Rail Projects: Using Experiences to Re-evaluate the Calspeed Estimates, California High Speed Rail Series, Working Paper No.156, April, The University of California Transportation Center, University of California, Berkeley, USA (Available at: http://www.uctc.net/research/papers/156.pdf, Accessed $1^{\text {st }}$ August 2016)

Liu, L., Wehbe, G., and Sisovic, J. (2010). The accuracy of hybrid estimating approaches. A case study of an Australian State road and traffic authority. The Engineering Economist, 55, pp.225-245.

Liu, J., Love, P.E.D., Matthews, J., Smith, J., and Sing, C-P. (2016). The praxis of performance measurement in public-private partnerships: Moving beyond the iron triangle. ASCE Journal of Management in Engineering 10.1061/(ASCE)ME.1943-5479.0000433

Love, P.E.D., Irani, Z., and Edwards, D.J. (2004). A rework reduction model for construction projects. IEEE Transactions on Engineering Management 51(4), pp.426-440. 
Love, P.E.D, Edwards, D.J., and Irani, Z. (2012a). Moving beyond optimism bias and strategic misrepresentation: An explanation for social infrastructure project cost overruns. IEEE Transactions on Engineering Management 59(4), pp. 560 - 571.

Love, P.E.D. Edwards, D.J., Irani, Z., and Sharif, A. (2012b). Participatory action research approach to public sector procurement selection. ASCE Journal of Construction, Engineering and Management, 138(3), pp.311-322.

Love, P.E.D. Zhou, J., Sing, C-P. and Kim, J.T. (2013). Documentation Errors in Instrumentation and Electrical Systems: Toward Productivity Improvement Using System Information Modelling. Automation in Construction, 35, pp.448-459.

Love, P.E.D., Simpson, I., Olatunji, O. Smith, J. and Regan, M. (2015a). Understanding the landscape of overruns in transportation infrastructure projects. Environment and Planning B: Planning and Design, 42(3), pp. 490 - 509.

Love, P.E.D., Sing, C-P., Carey, B. and Kim, J-T. (2015b). Estimating construction contingency: accommodating the potential for cost overruns in road construction projects ASCE Journal of Infrastructure Systems, 21(2) 04014035.

Love, P.E.D. Liu, J., Matthews, Sing, C-P., and Smith, J. (2015c). Future proofing PPPs: Lifecycle performance measurement and Building Information Modelling. Automation in Construction, 56, pp.26-35

Love, P.E.D., Ahiaga-Dagbui, D.D., and Irani, Z. (2016a). Cost overruns in transportation infrastructure projects: Sowing the seeds for a probabilistic theory of causation. Transportation Research A: Policy and Practice (In press)

Love, P.E.D., Zhou, J., Matthews, J. and Edwards, D.J. (2016b). Moving beyond CAD to an object-oriented approach for electrical control and instrumentation Systems. Advances in Engineering Software, 99, pp.9-17.

Loosemore, M. (2016). Social procurement in UK construction projects. International Journal of Project Management, 34, pp.133-144.

Lundberg, M., Jenpanitsub, A and Pyddoke, R. (2011). Cost overruns in Swedish transport projects. CTS Working Paper, Centre for Transport Studies, KTH, Stockholm, Sweden Mangieri G. (2016). Massive, unresolved rail costs loom despite chair's resignation. $11^{\text {th }}$ April 2016, (Available at: http://khon2.com/2016/04/11/massive-unresolved-rail-costs-loom-despite-chairs-resignation/,Accessed $2^{\text {nd }}$ August) 
Martin, S. (2011). Reviewing the last decade of public transport infrastructure projects in Australia. Proceedings of the Transport Research Forum, $28^{\text {th }}-30^{\text {th }}$ September, Adelaide, South Australia (Available at: www.patrec.org/artf.aspx, Accessed $9^{\text {gh }}$ August 2016)

Matsumoto, M., and Nishimura, T. (1998). Mersenne Twister: A 623-dimensionally equidistributed uniform pseudo-random number generator. ACM Transactions on Modelling and Computer Simulation, 8(1), pp.3-30.

Muriro, A., and Wood, G. (2011). A comparative analysis of procurement methods used on competitively tendered office projects in the UK. Royal Institution of Chartered Surveyors Legal Research Symposium, COBRA 2010, $2^{\text {nd }}$ and $3^{\text {rd }}$ September, Dauphine Universite, Paris, France. (Available at: http://usir.salford.ac.uk/23055/1/download_feed.pdf, Accessed 10 ${ }^{\text {th }}$ August 2016)

Moore, T. (2016). Government orders audit into Moreton Bay rail link debacle. May $30^{\text {th }}$, (Available at: http://www.brisbanetimes.com.au/queensland/government-orders-audit-into-moreton-bay-rail-link-debacle-20160530gp7fsb.html, Accessed $9^{\text {th }}$ August 2016)

NSW Audit Office. (2010). Transport Infrastructure Development Corporation. The AuditorGeneral's Report to Parliament, Sydney, New South Wales (NSW), (Available at: http://www.audit.nsw.gov.au/ArticleDocuments/187/26_Vol_9_2010_Transport_Infrastructure.pdf.aspx?Embed=Y, Accessed 9 $9^{\text {th }}$ August 2016)

Odeck, J. (2004) Cost overruns in road construction - what are their sizes and determinants. Transport Policy, 24, pp.43-53.

Odeck, J., Welde, M., and Volden, G.H. (2015). The impact of external quality assurance of costs estimates on cost overruns: Empirical evidence from the Norwegian road sector. European Journal of Transport Infrastructure Research, 15(3), pp.286-303.

Osland O, and Strand A, (2010). The politics and institutions of project approval: criticalconstructive comment on the theory of strategic misrepresentation. European Journal of Transport and Infrastructure Research 10 pp.77-88.

Peplow, M. (2016). London's Crossrail is a $\$ 21$ Billion test of virtual modelling. IEEE Spectrum $24^{\text {th }}$ March (Available at http://spectrum.ieee.org/transportation/mass-transit/londons-crossrail-is-a-21-billion-test-of-virtualmodeling, Accessed $10^{\text {th }}$ August 2016)

Pickrell, D.H. (1990). Urban Rail Transit Projects: Forecast versus Actual Ridership and Cost. Publication DOT-T 91-04, US Department of Transportation, October (Available at: http://people.plan.aau.dk/ mortenn/misc/alon/Pickrell\%20(1990)\%20Urban\%20Rail\%20Transit\%20Projects\%20Forecast\%20Versus\%2 0Actual\%20Ridership\%20and\%20Cost.pdf, Accessed 10 ${ }^{\text {th }}$ August 2016) 
Rahman, M., \& Alhassan, A. (2012). A contractor's perception on early contractor involvement. Built Environment Project and Asset Management, 2(2), 217-233.

Rowlinson, S. (1999). A definition of procurement systems. In. Rowlinson, S., and P. McDermott. Procurement Systems: A Guide to Best Practice in Construction. E \& F Spon, London, pp.27-53.

Saulwick, J. (2014). Sydney light rail line costs blow out to $\$ 2.2$ billion - $\$ 600$ million more than budgeted. Sydney Morning Herald, $10^{\text {th }}$ November, Available at: http://www.smh.com.au/nsw/sydney-lightrail-line-costs-blow-out-to-22-billion--600-million-more-than-budgeted-20141109-11jazn.html, Accessed 3 ${ }^{\text {rd }}$ August 2016

Siemiatycki, M. (2009). Comparing perspectives on transportation project cost overruns. Journal of Planning Education and Research, 29(2) pp.142-156.

Sing, C.P., Love, P.E.D., Tam, C.M. (2012). Multiplier model for forecasting manpower demand. ASCE Journal of Construction, Engineering and Management, 138(10), pp. 1161-1168.

Sing, M. C. P., Love, P. E. D., Edwards, D., and Liu, J. X. (2016). Dynamic modeling of workforce planning for infrastructure projects. Journal of Management in Engineering, 04016019.

Shields, P. and Rangarjan, N. (2013). A Playbook for Research Methods: Integrating Conceptual Frameworks and Project Management. Stillwater, OK, New Forums Press.

Smith, J, Jagger, D., Love, P.E.D. and Olatunji, O. (2016). Building Cost Planning for the Design Team. 3rd Edition, Routledge, Abingdon, Oxon, UK.

Verweji, S., Van Meerkerk, I.F., and Korthagen, I.A. (2015). Reasons for contract changes in implementing Dutch transportation infrastructure projects: An empirical exploration. Transport Policy, 37(1), pp.195-202

VAGO. (2010). Management of Major Rail Projects. Victorian Auditor General's Office Report 2009-10:31,23 ${ }^{\text {rd }}$ June, Melbourne, Victoria (Available at: http://www.audit.vic.gov.au/publications/200910/20100623-major-rail-full-report.pdf, Accessed $9^{\text {th }}$ August 2016)

Vidalis, S.M and Najafi, F.T. (2004) Cost and time overruns in highway construction. Proceedings of $4^{\text {th }}$ Transportation Specialty Conference of Canadian Society of Civil Engineering, Canadian Society of Civil Engineering, Montreal, QC, Canada. 
Table 1. Cost information for rails projects constructed between 2011 and 2014 by geographical region $(n=16)$

\begin{tabular}{|c|c|c|c|c|c|c|c|c|}
\hline Project Type & $\begin{array}{c}\text { Procurement } \\
\text { Method }\end{array}$ & Classification & State & $\begin{array}{c}\text { Original Contract } \\
\text { Value (\$) }\end{array}$ & $\begin{array}{c}\text { Final Contract } \\
\text { Value }(\$)\end{array}$ & $\begin{array}{c}\text { Cost } \\
\text { Difference }\end{array}$ & $\begin{array}{l}\% \text { Cost } \\
\text { Change }\end{array}$ & $\begin{array}{c}\text { Scope } \\
\text { Changes (\$) }\end{array}$ \\
\hline $\begin{array}{l}\text { Installation and Maintenance of } \\
\text { Concrete Sleepers }\end{array}$ & $\begin{array}{l}\text { Traditional } \\
\text { Lump Sum }\end{array}$ & $\begin{array}{l}\text { Up-grade and } \\
\text { Maintenance }\end{array}$ & $\begin{array}{l}\text { Western } \\
\text { Australia }\end{array}$ & $12,905,657$ & $12,386,515$ & $-519,141$ & -4.19 & $-403,581$ \\
\hline $\begin{array}{l}\text { Track Extension and Installation of a } \\
\text { Crossing }\end{array}$ & $\begin{array}{l}\text { Traditional } \\
\text { Lump Sum }\end{array}$ & New Build & $\begin{array}{l}\text { Western } \\
\text { Australia }\end{array}$ & $3,480,286$ & $3,418,423$ & $-61,863$ & -1.81 & $-61,863$ \\
\hline Modification and Upgrade of Track & $\begin{array}{l}\text { Traditional } \\
\text { Lump Sum }\end{array}$ & $\begin{array}{l}\text { New Build and } \\
\text { Up-grade }\end{array}$ & $\begin{array}{l}\text { Western } \\
\text { Australia }\end{array}$ & $5,404,773$ & $6,382,221$ & 977,448 & 15.32 & 977,448 \\
\hline Iron Ore Track Extension (Spur Line) & $\begin{array}{l}\text { Traditional } \\
\text { Lump Sum }\end{array}$ & New Build & $\begin{array}{l}\text { Western } \\
\text { Australia }\end{array}$ & $3,293,777$ & $3,715,808$ & 422,030 & 11.36 & 422,030 \\
\hline Track Maintenance & $\begin{array}{l}\text { Traditional } \\
\text { Lump Sum }\end{array}$ & Maintenance & $\begin{array}{l}\text { New South } \\
\text { Wales }\end{array}$ & $15,816,417$ & $17,040,378$ & $1,223,961$ & 7.18 & $1,223,961$ \\
\hline $\begin{array}{l}\text { Track Inspection and Maintenance } \\
\text { Depot }\end{array}$ & $\begin{array}{l}\text { Traditional } \\
\text { Lump Sum }\end{array}$ & New Build & $\begin{array}{l}\text { New South } \\
\text { Wales }\end{array}$ & $2,687,086$ & $3,585,429$ & 898,343 & 25.05 & 898,343 \\
\hline New Trackwork & $\begin{array}{l}\text { Traditional } \\
\text { Lump Sum }\end{array}$ & New Build & $\begin{array}{l}\text { Western } \\
\text { Australia }\end{array}$ & $2,501,453$ & $3,341,107$ & 839,653 & 25.13 & 839,653 \\
\hline Urban Light Rail & $\begin{array}{l}\text { Design and } \\
\text { Construct }\end{array}$ & New Build & $\begin{array}{l}\text { New South } \\
\text { Wales }\end{array}$ & $81,519,436$ & $106,472,525$ & $24,953,089$ & 23.44 & $24,953,089$ \\
\hline New Signals & $\begin{array}{l}\text { Traditional } \\
\text { Lump Sum }\end{array}$ & Up-grade & $\begin{array}{l}\text { South } \\
\text { Australia }\end{array}$ & $8,942,956$ & $9,761,790$ & 81,8834 & 8.39 & 81,8834 \\
\hline $\begin{array}{l}\text { Urban Rail Revitalization - } \\
\text { Electrification }\end{array}$ & $\begin{array}{l}\text { Design and } \\
\text { Construct }\end{array}$ & Electrification & $\begin{array}{l}\text { South } \\
\text { Australia }\end{array}$ & $15,037,635$ & $17,333,340$ & $2,295,705$ & 13.24 & $2,295,705$ \\
\hline $\begin{array}{l}\text { Regional Rail ( Includes new track and } \\
\text { station, bridge refurbishment) }\end{array}$ & $\begin{array}{l}\text { Alliance } \\
\text { Contract }\end{array}$ & $\begin{array}{l}\text { New Build and } \\
\text { Upgrade }\end{array}$ & Victoria & $318,307,311$ & $353,376,242$ & $35,068,931$ & 9.92 & $35,068,931$ \\
\hline Urban Rail (Track Extension) & $\begin{array}{l}\text { Traditional } \\
\text { Lump Sum }\end{array}$ & New Build & $\begin{array}{l}\text { Western } \\
\text { Australia }\end{array}$ & $23,959,264$ & $25,385,033$ & $1,425,769$ & 5.62 & $1,027,891$ \\
\hline Freight Track & $\begin{array}{l}\text { Traditional } \\
\text { Cost-Plus }\end{array}$ & New Build & $\begin{array}{l}\text { Western } \\
\text { Australia }\end{array}$ & $12,748,006$ & $28,369,461$ & $15,621,455$ & 55.06 & $15,621,455$ \\
\hline Urban Track Upgrade & $\begin{array}{l}\text { Traditional } \\
\text { Lump Sum }\end{array}$ & $\begin{array}{l}\text { New Build and } \\
\text { Upgrade }\end{array}$ & $\begin{array}{l}\text { Western } \\
\text { Australia }\end{array}$ & $29,914,480$ & $31,352,254$ & $1,437,774$ & 4.59 & $1,437,774$ \\
\hline Iron Ore Track Extension (Spur Line) & $\begin{array}{l}\text { Traditional } \\
\text { Cost-Plus }\end{array}$ & $\begin{array}{l}\text { New Build and } \\
\text { Upgrade }\end{array}$ & $\begin{array}{l}\text { Western } \\
\text { Australia }\end{array}$ & $1,851,459$ & $6,867,640$ & $5,016,181$ & 73.04 & $5,016,181$ \\
\hline Iron Ore New Build & $\begin{array}{l}\text { Traditional } \\
\text { Cost-Plus }\end{array}$ & New Build & $\begin{array}{l}\text { Western } \\
\text { Australia }\end{array}$ & $1,200,000$ & $36,691,197$ & $35,491,197$ & 96.73 & $35,491,197$ \\
\hline
\end{tabular}


Table 1: Descriptive statistics for cost change

\begin{tabular}{|l|c|}
\hline \multicolumn{1}{|c|}{ Statistic } & $\begin{array}{c}\text { Value } \\
(\%)\end{array}$ \\
\hline Range & 100.92 \\
\hline Mean & 23.00 \\
\hline Variance & 793.15 \\
\hline Std. Deviation & 28.16 \\
\hline Coef. of Variation & 1.22 \\
\hline Std.Error & 7.04 \\
\hline Skewness & 1.70 \\
\hline Excess Kurtosis & 2.33 \\
\hline Min & -4.19 \\
\hline $5 \%$ & -4.19 \\
\hline $10 \%$ & -2.52 \\
\hline $25 \%$ (Quartile 1) & 6.01 \\
\hline $50 \%$ (Median) & 12.3 \\
\hline $75 \%$ (Quartile 3) & 25.11 \\
\hline $90 \%$ & 80.14 \\
\hline $95 \%$ & 96.73 \\
\hline Max & 96.73 \\
\hline
\end{tabular}


Table 3. Goodness of Fit Tests

\begin{tabular}{|l|c|c|c|c|}
\hline Distribution Type & $\begin{array}{c}\text { Sig. } \\
\boldsymbol{\alpha} \text { Level }\end{array}$ & $\begin{array}{c}\text { Kolmogorov- } \\
\text { Smirnov }(\boldsymbol{D}) \\
\text { Critical Value }\end{array}$ & $\begin{array}{c}\text { Anderson } \\
\text { Darling }\left(\boldsymbol{A}^{\mathbf{2}}\right) \\
\text { Critical Value }\end{array}$ & $\begin{array}{c}\text { Chi-squared } \\
\left(\boldsymbol{\chi}^{\mathbf{2}}\right) \\
\text { Critical Value }\end{array}$ \\
\hline \multirow{3}{*}{$\begin{array}{l}\text { Frechet 3P } \\
\text { (Rail Projects) }\end{array}$} & $\mathbf{0 . 2}$ & 0.25778 & 1.3749 & 1.6424 \\
\cline { 2 - 5 } & $\mathbf{0 . 1}$ & 0.29472 & 1.9286 & 2.7055 \\
\cline { 2 - 5 } & $\mathbf{0 . 0 5}$ & 0.32733 & 2.5018 & 3.8415 \\
\cline { 2 - 5 } & $\mathbf{0 . 0 2}$ & 0.36571 & 3.2892 & 5.4119 \\
\cline { 2 - 5 } & $\mathbf{0 . 0 1}$ & 0.39201 & 3.9074 & 6.6349 \\
\hline
\end{tabular}


Table 4. Examples of probabilities of cost changes

\begin{tabular}{|c|c|c|c|c|c|}
\hline $\begin{array}{c}\text { Probability Cost } \\
\text { Change }\end{array}$ & $\mathbf{P}(\mathbf{X}<\mathbf{X 1})$ & $\mathbf{P}(\mathbf{X}>\mathbf{X 1})$ & $\mathbf{P}(\mathbf{X 1}<\mathbf{X}<\mathbf{X 2})$ & $\mathbf{P}(\mathbf{X}<\mathbf{X 2})$ & $\mathbf{P}(\mathbf{X}>\mathbf{X 2})$ \\
\hline 1 and 5\% & 0.13 & 0.87 & 0.12 & 0.25 & 0.75 \\
\hline 6 and 10\% & 0.28 & 0.72 & 0.12 & 0.40 & 0.60 \\
\hline 11 and 15\% & 0.43 & 0.57 & 0.09 & 0.53 & 0.47 \\
\hline 16 and 20\% & 055 & 0.45 & 0.08 & 0.62 & 0.38 \\
\hline 21 and 25\% & 0.64 & 0.36 & 0.06 & 0.70 & 0.30 \\
\hline 26 and 30\% & 0.71 & 0.29 & 0.04 & 0.75 & 0.25 \\
\hline
\end{tabular}




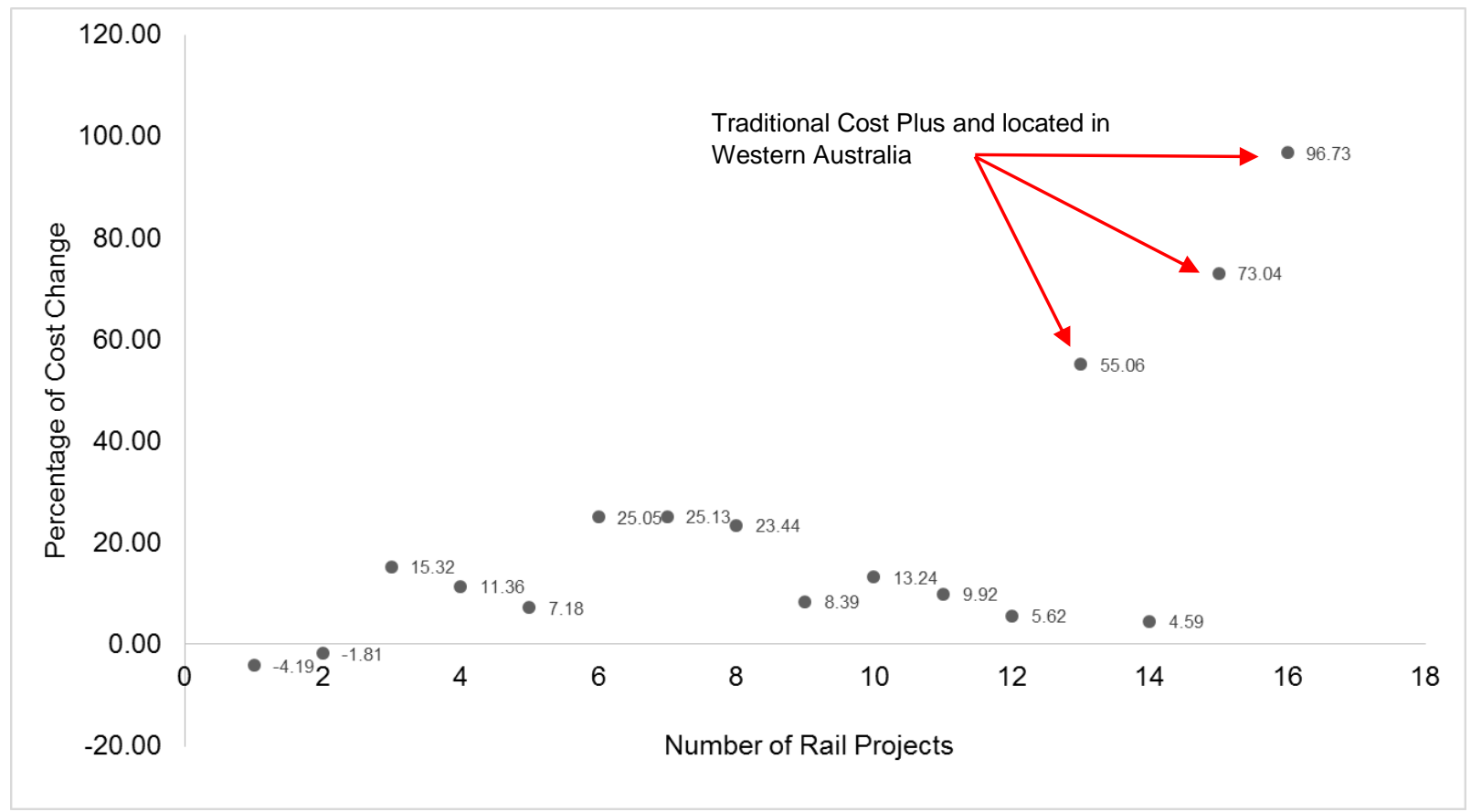

Figure 2. Scatterplot of rail projects 


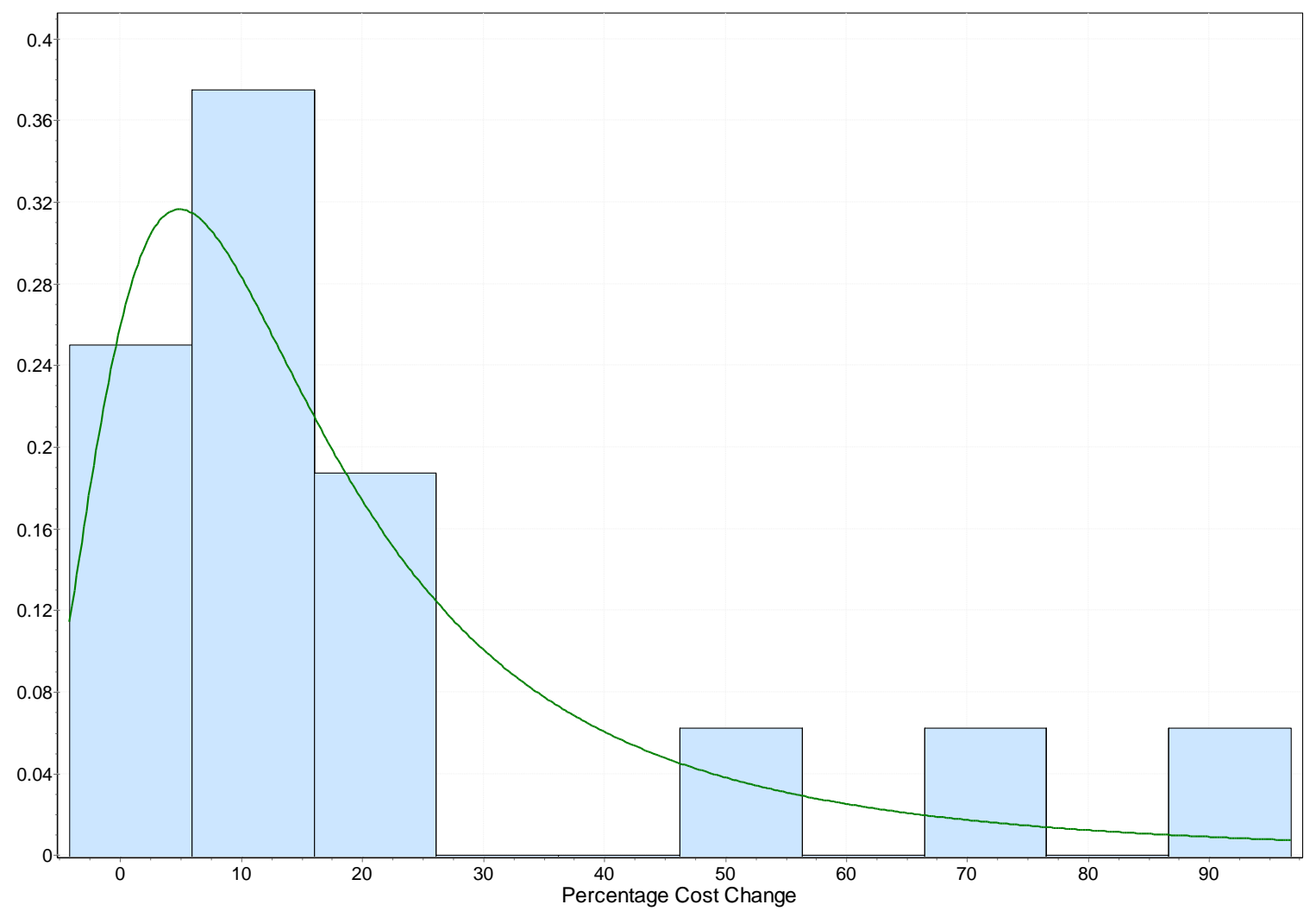

Figure 2. Frechet 3P: PDF for cost change 


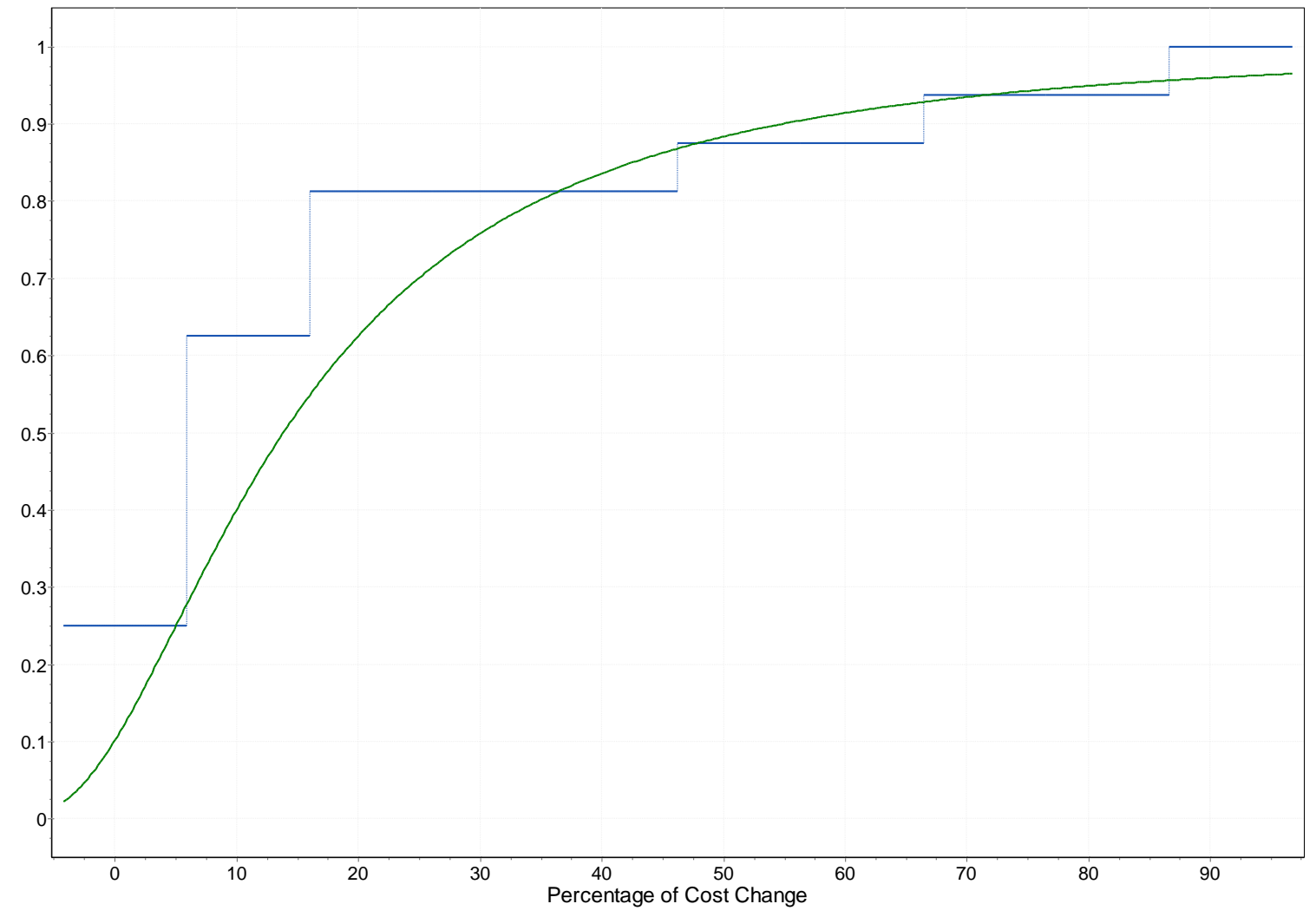

Figure 3. Frechet 3P: CDF for cost change 


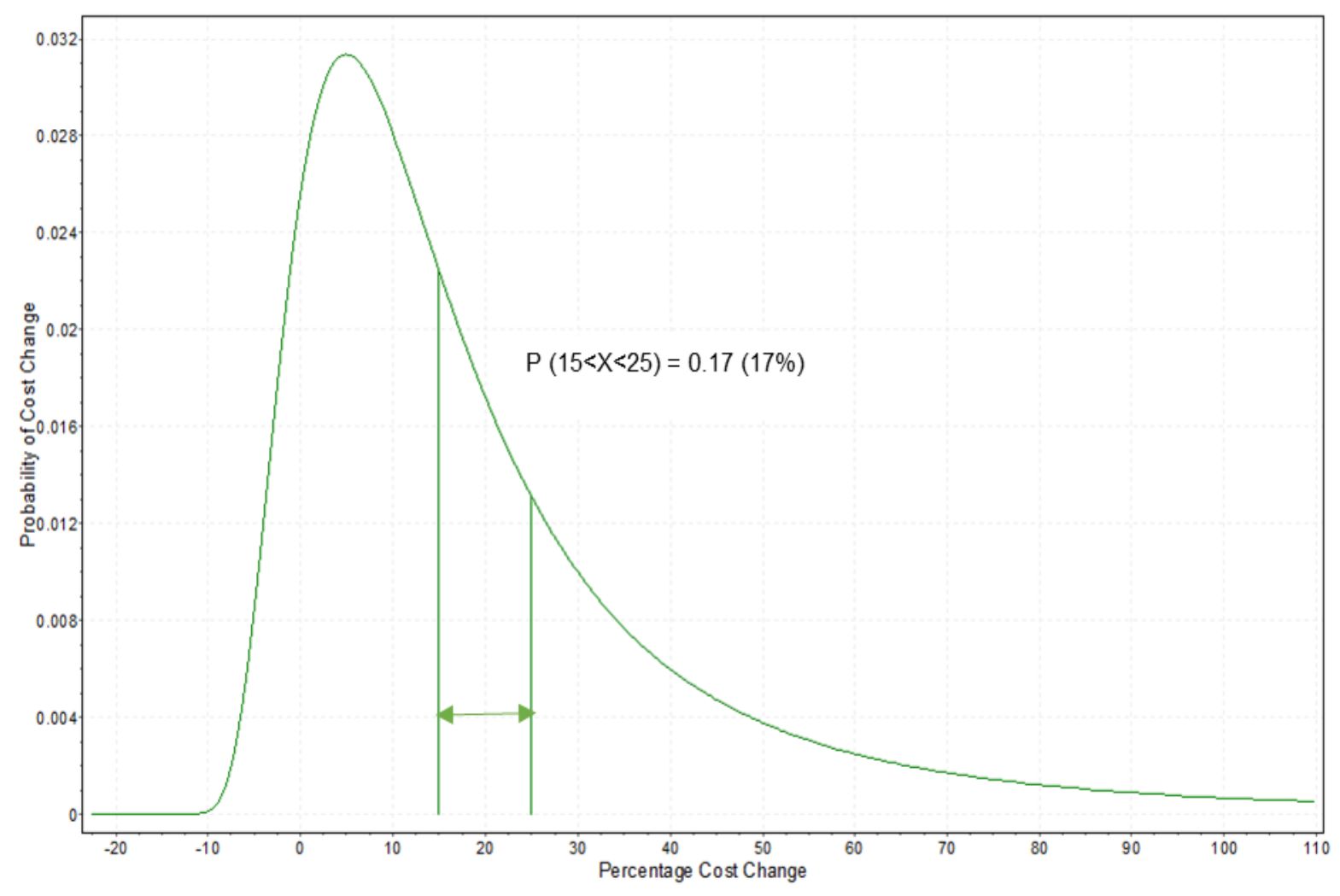

Figure 4. PDF with delimiters between $15 \%$ and $25 \%$ cost change 


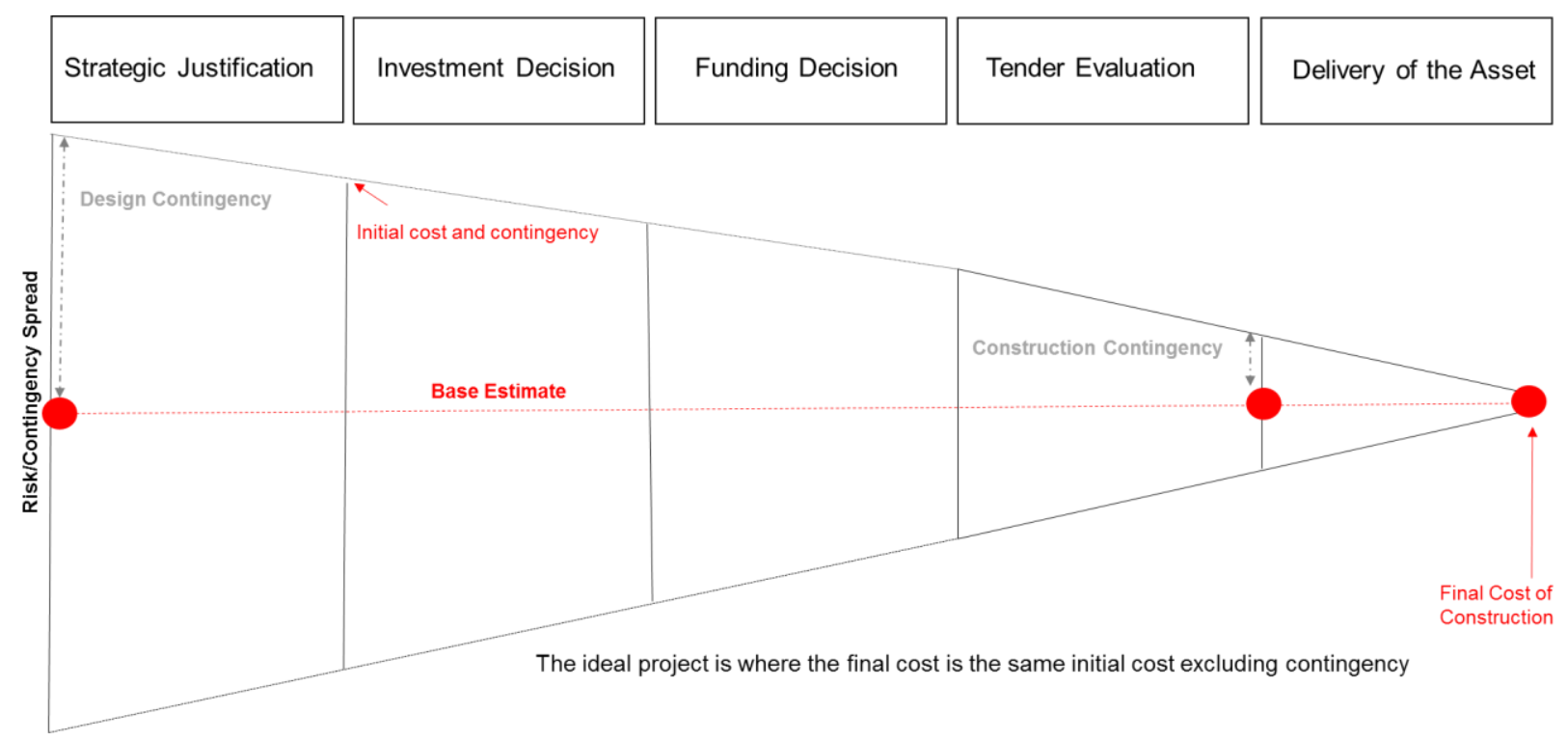

Adapted from: Department of Transport and Main Roads (2015:p.4)

Figure 5. The ideal cost scenario 


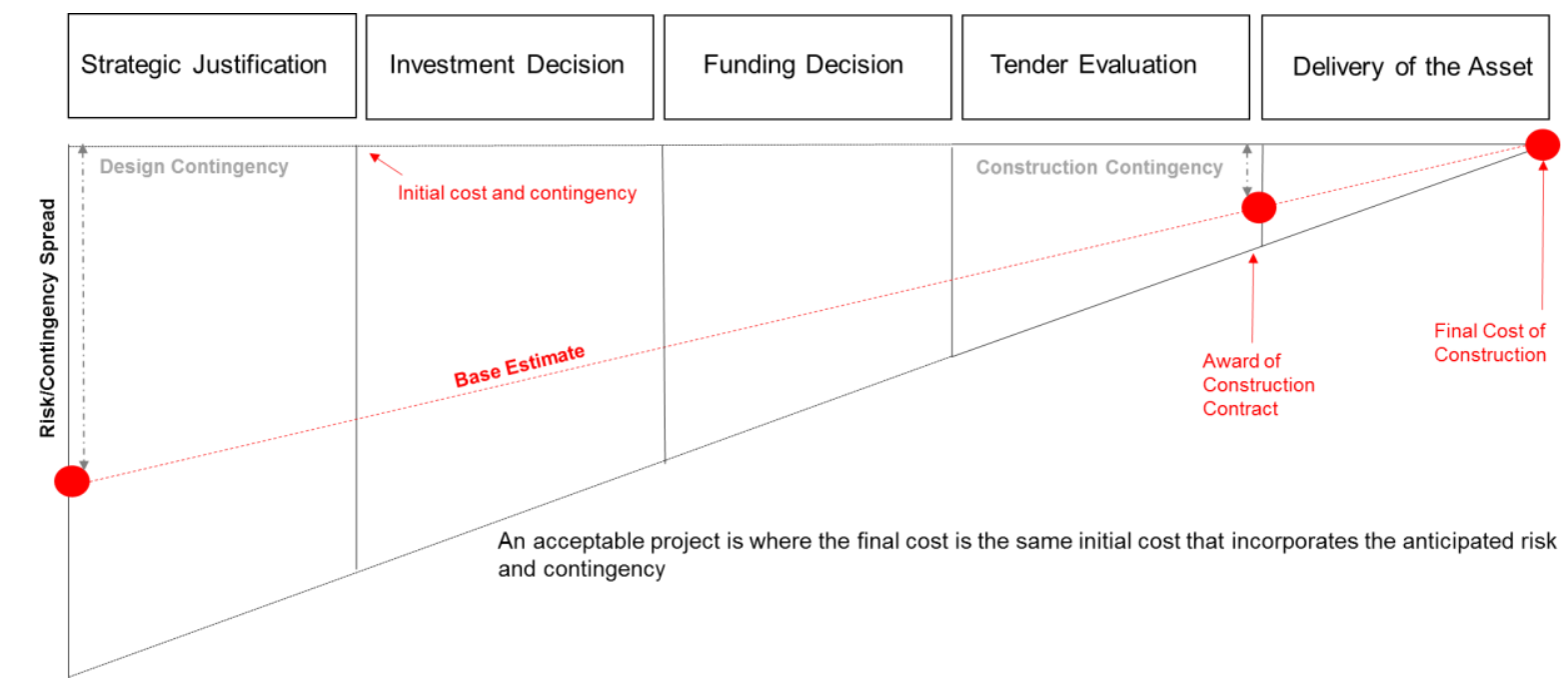

Adapted from: Department of Transport and Main Roads (2015:p.5)

Figure 6. An acceptable cost scenario 


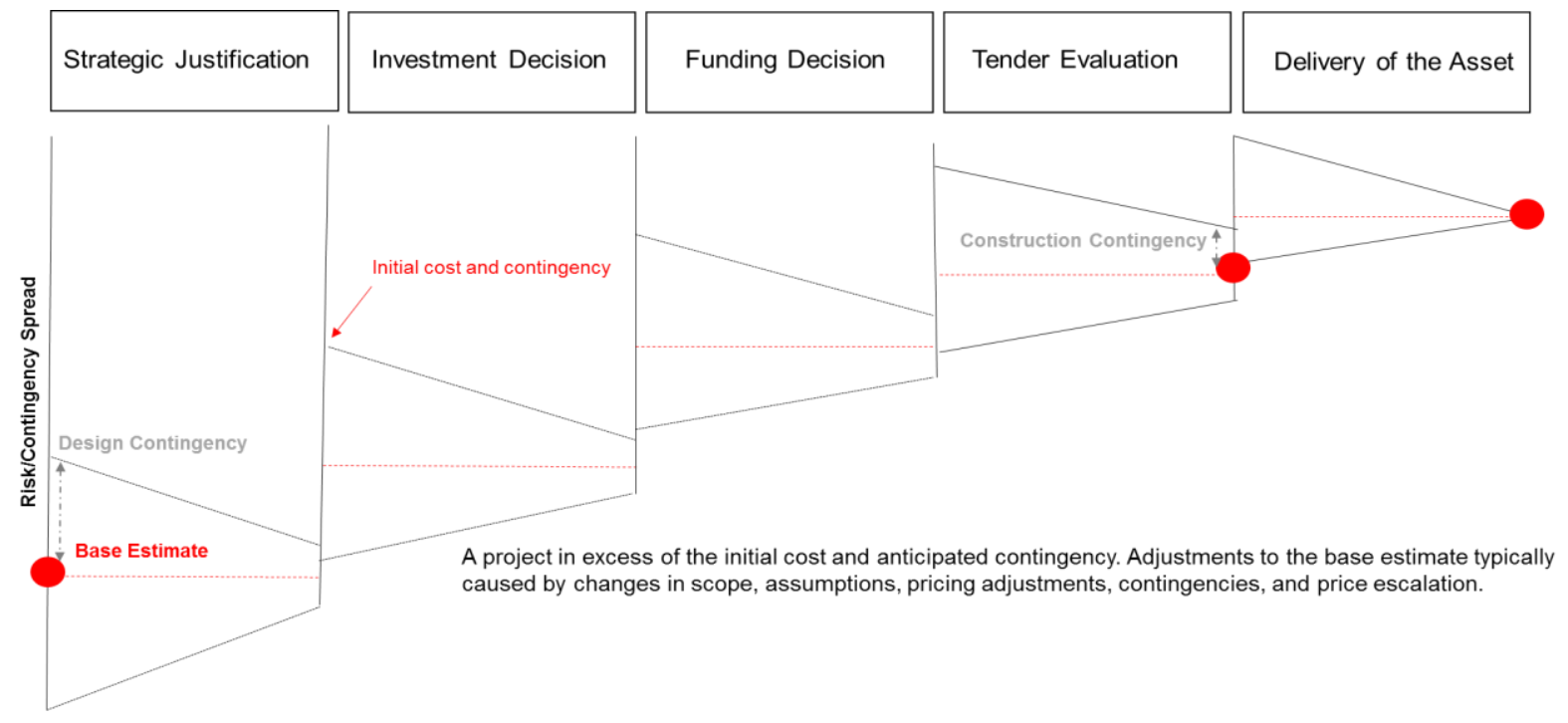

Adapted from: Department of Transport and Main Roads (2015:p.5)

Figure 7. Unacceptable cost scenario 


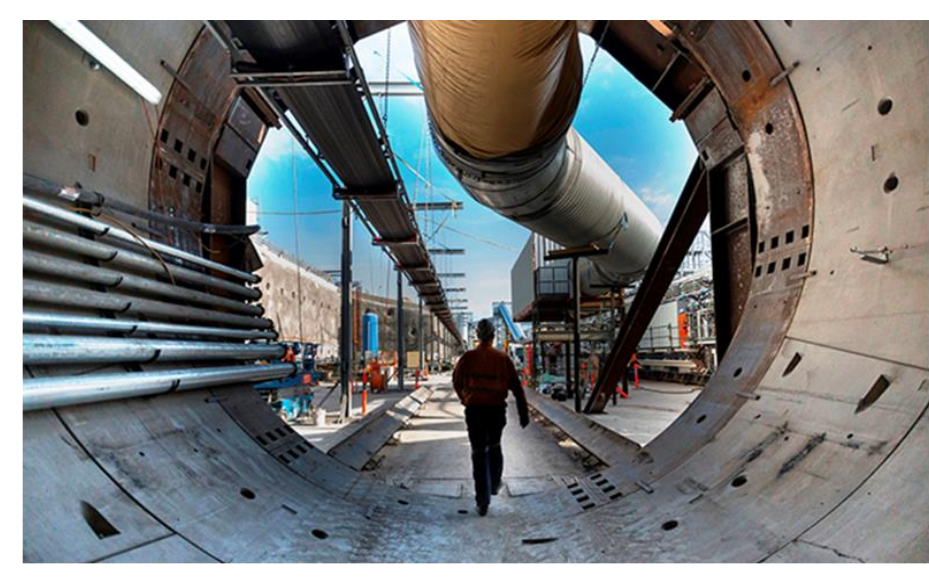

a. Realistic view of a rail tunnel

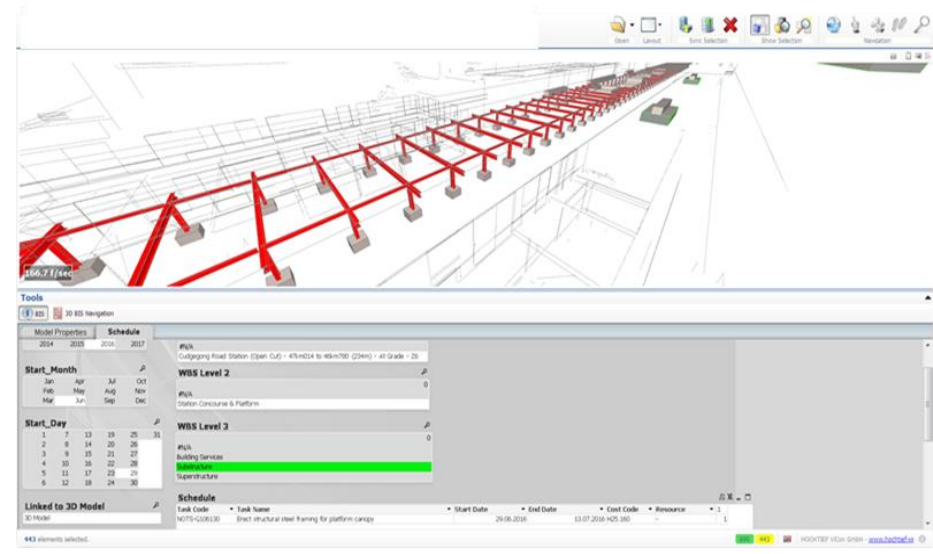

c. 4D Schedule progress of track progress

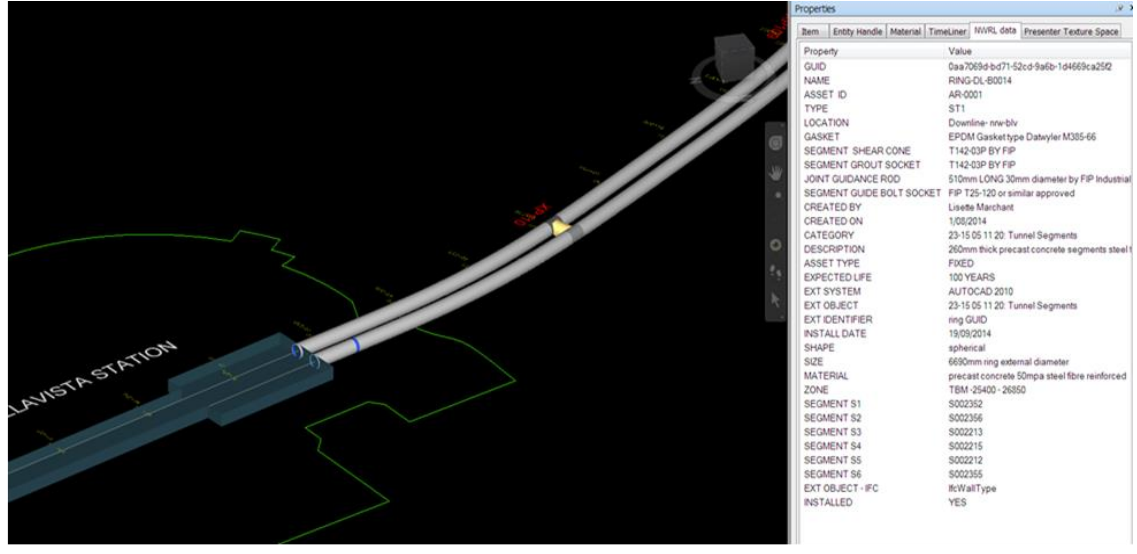

b. Tunnel Boring Machine using Geographical Information Systems

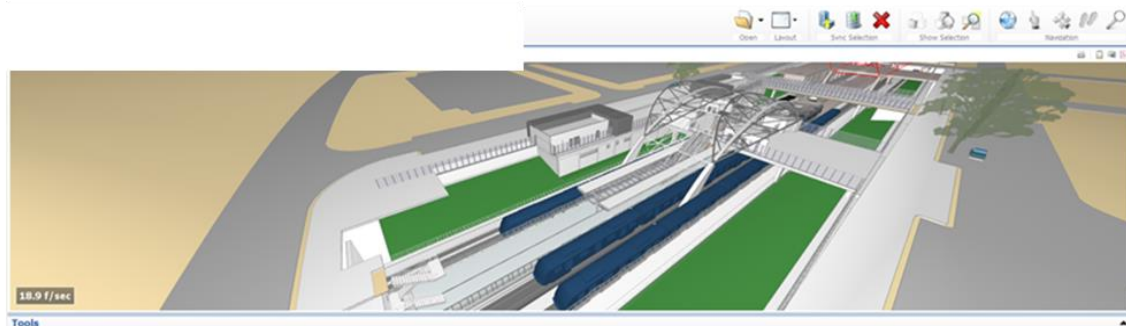

$$
\text { malina }
$$

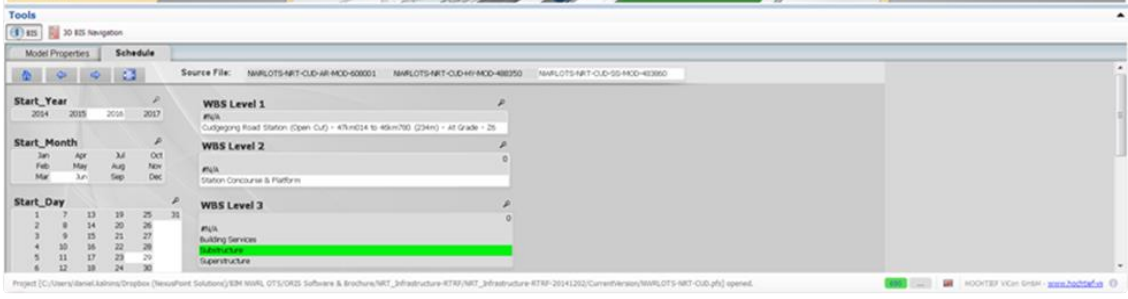

d. 5D progress of schedule and cost of a Station

Figure 8. Extracts from a Building Information Model for a rail project 


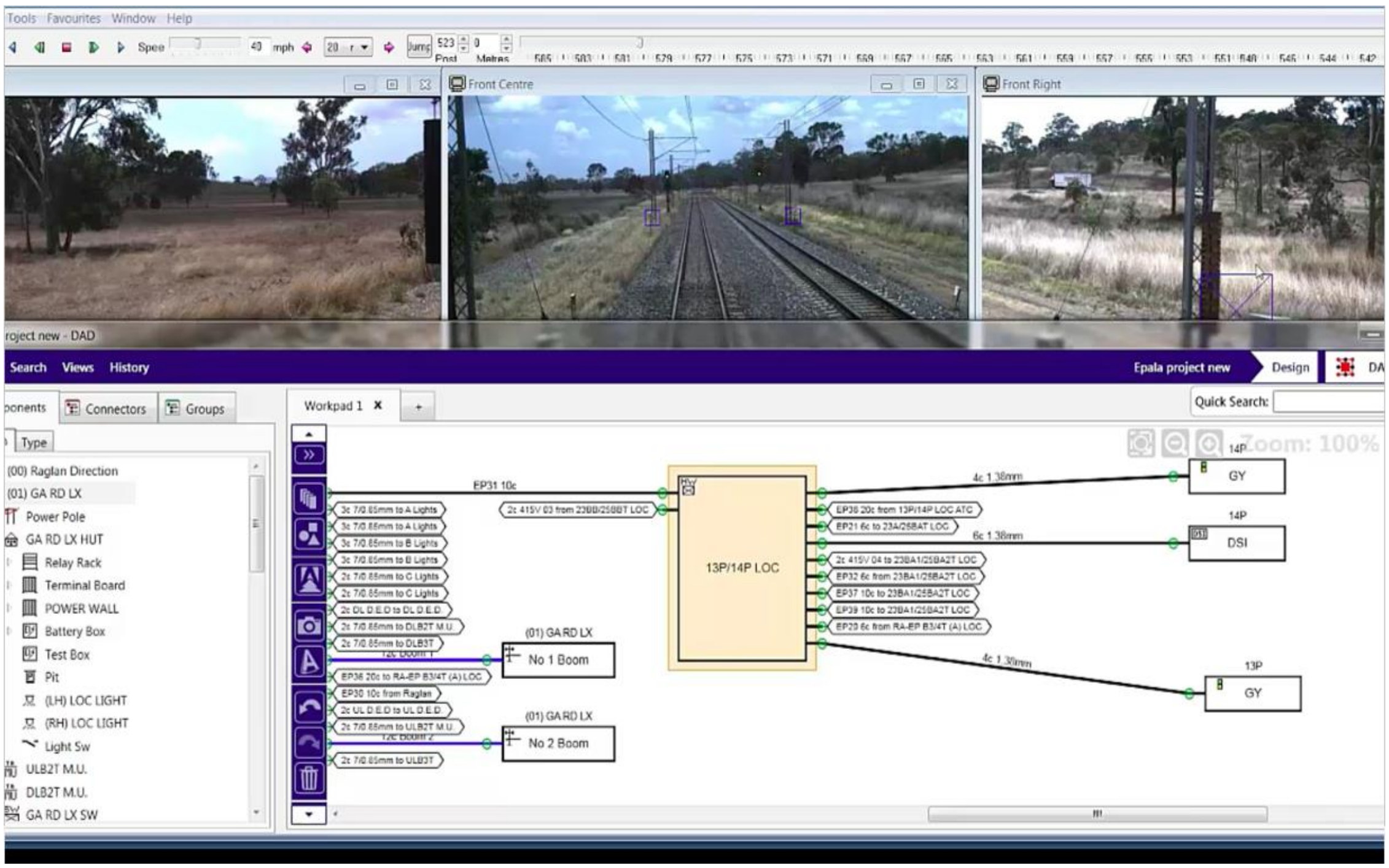

Figure 9. Creation of a Systems Information Model for a rail project 